\title{
ミズガヤツリおよびハマスゲの精油成分
}

\author{
(1976 年 7 月 20 日受理)
}

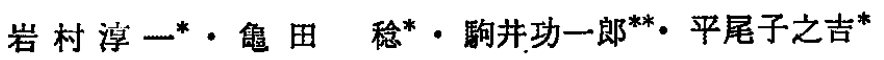

ミズガヤッリの精油を機器分析で一部は化学的処理を併用して, 13 種のセスキテルペン系化合物を確

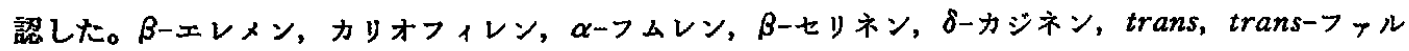

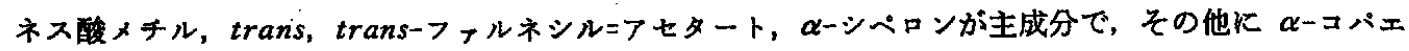
ン, $\beta$ ーサンタレン, $\beta$ ーグフイエン, カラメネン, シペロタンドンのュン跡を含んでいた。

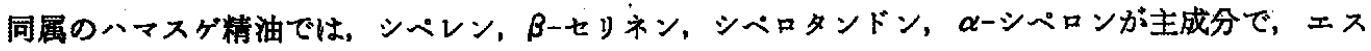
テルは想められなかった。

ミズガヤッッとハマスゲは近緑種であるが，前者が鎖状セスキテルペンのエステルを主成分とするの に対し，後者は環状ケトンを主成分とし，テルペン酸エスデルを含まないことが特徽である。

\section{1 㒂雷}

ミズガヤッョ(Cyperus serotinus Rottb.) とハマスゲ (Cyperus rotundus L.) はカヤッリグサ科 (Cyperaceae) の多年生草本 で, 前者は水田に, 後者は耕地などに生育, とすに地下茎で繁殖 する取除し難い蒮草である。

ハマスダの乾嬠塊茎は番附子と称する漠方楽て，精油成分とし

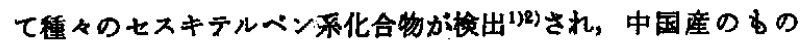
について少量のモノテルペン颣が報告されている。ミズガヤッり の精油成分の研究恃見られない。著者らは Cyperaceae の化学 分䫏学的研究の一謤として，本精油成分を明らかとすることを目 的として機器分析に化学的処理を併用し，組成成分の梌討を試々 たので報告する。

\section{2 实駼}

\section{1 精油の採集}

ミスガャツリ：1975年 3 月奈良粽吉野郡の水田で採取したすの

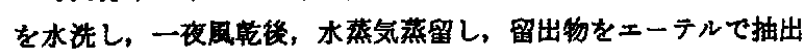

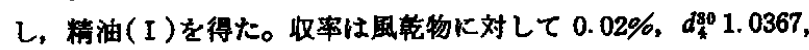
$n \mathrm{~b}^{\circ} 1.4949,[\alpha]_{6}^{24} \pm 0^{\circ}\left(c=0.9, \mathrm{CHCl}_{s}\right)$ ， た 1976 年 3 月敦䐝 市水田から採取したものを，同様に処理し精油（II）を得た。収率 $0.01 \%$.

八マスゲ：1976年 3 月爱泼県の果樹園で䌽取し, 同様に処理し

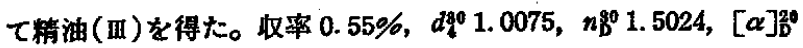
$+21.6^{\circ}(c=2.0, \mathrm{EtOH})$ 。主北朝鲜産の市眅香附子から同㥞に 採取し，精油(N)とした。取率 $1.21 \% ， d_{4}^{30} 1.0678 ， n_{\mathrm{D}}^{80} 1.4997$ ， $[\alpha]_{B}^{20}+19.3(c=1.6, \mathrm{EtOH})$ 。

* 近戴大学理工学部沈用化学教室, 577 東大眨市小若江

** 近业大学费学部费芸化学教室, 577 東大䛀市小若江

1) B. Jrivedi, O. Mot1, V. Herout, F. Sorm, Collect. Caech. Chem. Commun., 29, 1675 (1964) ; 木村婎四郎, 大谷正 䕁誌, 48, 971(1928).

2) H. Hikino, K. Aota, T. Takemoto, Chem. Pharm. Bull., 16. 1900 (1968).
ミズガヤッリ精油のガスクロマトグラム（GLC）性奈良県産陚 料で 23 ピーク，敦賀市産試料で 34 ピークを認め，主成分を示す ピークは七つ，他は僅少量のピークであった。ハマスゲ精油のガ スクロマトグラムは要媛県産試料で 34 ピーク, 香附子精油で 39 のピークを示し，主成分を示すピーク恃四つ，他恃壦少量成分て あった。

\section{2 精油成分の分讙}

ミズガヤシリ精油 $100 \mathrm{mg}$ をアルミナを充てんしたカラム $(40$ $\mathrm{cm} \times$ 内径 $1.5 \mathrm{~cm})$ を用い, カラムクロマトグラフィー (CC) を 行なった。溶媒はへキサン, ペンゼン, エーテル, エタノールの 順飞展開した。岑化水素はーキサンに; trans, transーファル* ス酸メナルはベンゼン溶出夜の前半に汪汪単品として溶出した。

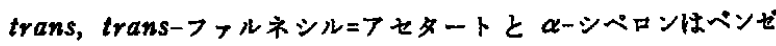
ン溶出没の後半からェタノール溶出漼の前半にかけて涺合物とし て溶出した。ハマスゲの精油の上記同様に処理した。上記処理に より分離した各成分を必要に応じて GLC 分取を併用して単離を 行ない，分析わるいは化学的処理に用いた。

\section{3 撒㗊分析}

旋光度は日立旋光計 PO-B 型を用い、エタノール溶液で期定し た。

ガスクロマトグラムは柳本 G-8， G-1800 型で，5\%または25 \% PEG $20 \mathrm{M}(60 \sim 80$ メッシュ) あるいは $5 \% \mathrm{SE} \mathrm{30}(60 \sim 80$ × ッシュ) カラムを用い,カラム温度 $60 \sim 200^{\circ} \mathrm{C}$ (昇温 $4^{\circ} \mathrm{C} / \mathrm{min}$ ), ヘリウムの流速 $15 \mathrm{~m} l / \mathrm{min} て ゙$ 溂定した。

紫外吸取スペクトル (UV) は日立紫外咋収スペクトルUV-323 型を用い,ェタノール溶液で測定した。

赤外昅取スペクトル (IR) は日本分光赤外吸光スペクトル $\mathbb{R}$ A 2 型を用い，液膜法で湘定した。

核磁気共鳴スペクトル（NMR）は日立核磁氛共鳴スペクトル R-24 型を用い，重クロロホルム中，TMSを内部標準として湖 定し、の值 $(\mathrm{ppm})$ で示した。

質量スペクトル (MS) は島津 LKB-GC-MS 9000 型を用い, 加速電圧 $3500 \mathrm{~V} ，$ イオン化電压 20 立大は $70 \mathrm{eV}, 10 \%$ PEG 20 
Table 1 Composition of the essential oils of Cyperus serotinus Rottb. $(1$, II) and Cyperus rotundus L. (III, $\mathbb{N}$ )

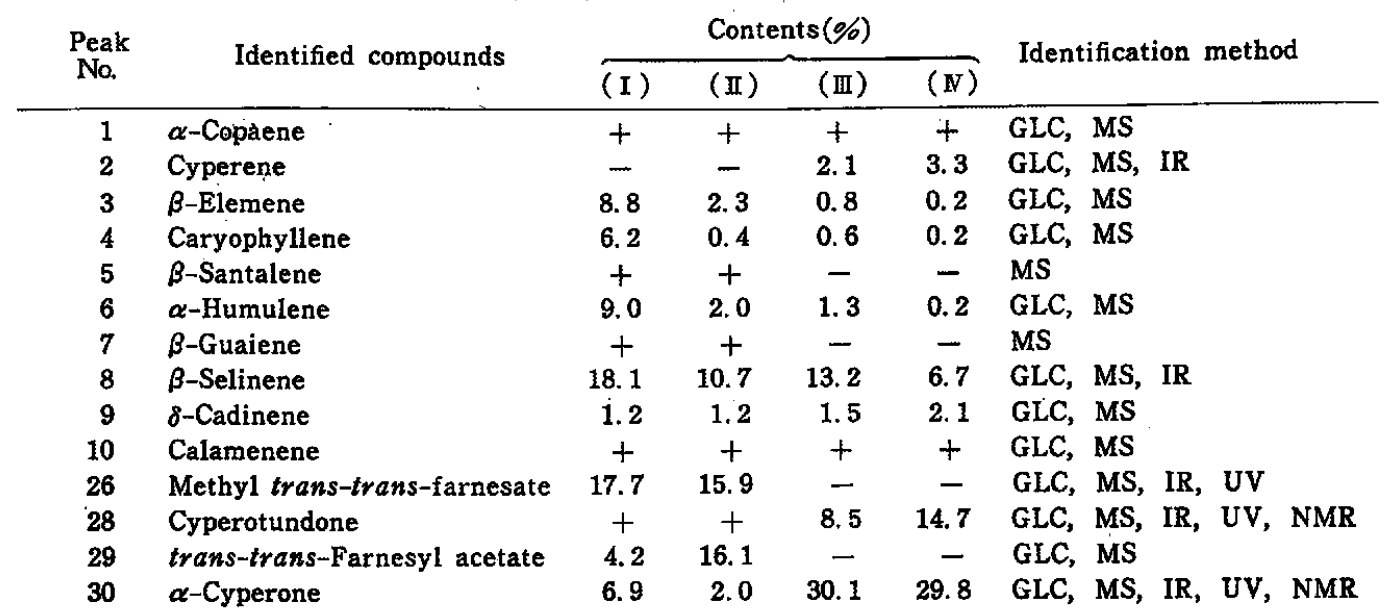

+ : trace.

$\mathrm{M}$ (Chromosorb W, 60 80メッシュ, $\$ 3 \mathrm{~mm} \times 2.0 \mathrm{~m}$, ガラス 制) カラム, カラム溫度 $100 \sim 160^{\circ} \mathrm{C}$, ヘリウムの流速 $25 \mathrm{ml}$ $\min$ て測定した。

\section{4 精油成分の同定}

2.4.1 炭化水寨部 : GLCの保持時間（以下 $t_{\mathrm{R}}$ と略記する） たはMSスペクトルのフラグメントパターンが標品と一致したこ

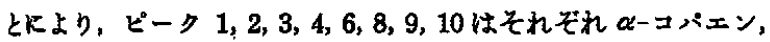

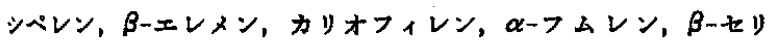
ネン, $\delta$-カジネン，カラメネンであることを確認した。またビー ク2および8については IR であ同定した。

ピーク 5,7の MS スペクトルのフヨグメントバターンは文隔》 記载のそれと一致したことから，前者は $\beta$-サンタレン，後者は

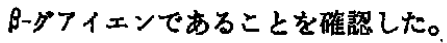

2.4 .2 含酸素成分：ミズガヤッリ精油のガスクロマトグラム, ピーク 26，29，30 は主成分を示し，ピーク 26 は CC でベンゼ ン部倰出し, 分取 GLC で単離後, IR, UV, MS スペクトル を制定した。MS スペクトルは M! m/e 250(13)‘)，特短的フラグ メントが $m / e$ 114(86), 69(100) に出現した。

$\operatorname{IR}\left(1720,1650,1220,1140 \mathrm{~cm}^{-1}\right)$ およびUVスべクト $\left(\lambda_{\max }^{\mathrm{RLOH}} 215 \mathrm{~nm}\right)$ は $\alpha, \beta$-不飽和酸のェステルの存在を示㥖した。 MS スペクトルKおいては M!の McLafferty 転位と思われる $m / e 136\left[\left(\mathrm{C}_{10} \mathrm{H}_{10}\right)^{+}:(53)\right], 114\left(\mathrm{C}_{6} \mathrm{H}_{10} \mathrm{O}_{2}\right)^{+}$, さらK m/e 136 の フラグメントからと思われる $69\left[\left(\mathrm{C}_{5} \mathrm{H}_{9}\right)^{+}\right]$占), 67[( $\left.\left.\mathrm{C}_{5} \mathrm{H}_{7}\right)^{+}:(12)\right]$ の各フラグメントが出現した。また分取 GLC で単離したビーク 26 をェーテル中，承冷下， $\mathrm{LiAlH}_{4}$ で㯰元した生成物的 GLC

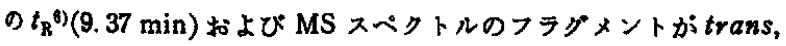
transーファルネッール $\left[\mathrm{IR}\left(\mathrm{cm}^{-1}\right): 3350,1010\right.$ (ヒドロキシル基), 1670 (二重結合), $\mathrm{MS}(m / e): \mathrm{M} \div 222(4), 69(100), \operatorname{NMR}(\delta)$ :

3) E. Stenhagen, S. Abrahamsson, E. W. McLafferty, "Registry of Mass Spectral Data", Vol.2, John Wiley and Sons, Inc., New York, N.Y. (1974) p.1024, 1026.

4)（）怔相対強度（\%).

5) 岩村淳一, 别府一夫, 平尾子之吉, 分析機器, 14, 112 (1976) ; 14, 162(1976).

6) $3 \%$-OV 17 カラム $(2 \mathrm{~m} \times$ 内径 $3 \mathrm{~mm})$, カラム温度 $180^{\circ} \mathrm{C}$.
$1.58(6 \mathrm{H}, \mathrm{s})$, オレフィンメチル $), 1.68(6 \mathrm{H}, \mathrm{s}$, オレフィンメ チル) で NMR スペクトルのオレフィンメチルは Bates らタの結 果に完全に一致]に一致するピークを認めた。

ピーク 26 trans, transーファルネス酸メチルと推定した。 一方、ファルネス酸メチルをCorey ら9のの方法で合成した。す なわち, 合成ファルネンールの酸化党で得たファルネサール $38 \mathrm{~g}$ をメタノール $300 \mathrm{ml}$ K溶解し，シフン化ナトリウム $45 \mathrm{~g}$ ，釄酸 $17 \mathrm{~g}$, Attenburrow ら ${ }^{11)}$ 方法で調慗した酸化マンガン $(\mathrm{N}) 320$

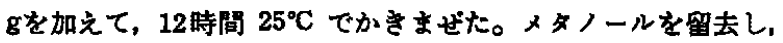
水でらすめ，エーテルで抽出し，無水硫䤇ナトリウムで乾嬠，エ 一テルを留去するとはとんど純粋なファルネス酸メチル（4異性 体混合物) を得た。生成物の GLC を測定するとそれぞれ 8.22, $9.30,9.76,10.82 \min \kappa t_{\mathrm{R}}{ }^{6)}$ 示した。ピーク 26 の GLCの $t_{\mathrm{R}}{ }^{6}(10.82 \mathrm{~min})$ は合成の trans, transーファルネス酸メチル $[\operatorname{NMR}(\delta): 1.40 \sim 2.10(12 \mathrm{H}, \mathrm{m}$, オレフィンメチル), 1.90〜 $3.10\left(8 \mathrm{H}, \mathrm{m},=\mathrm{C}-\mathrm{CH}_{2}-\right), 3.65\left(3 \mathrm{H}, \mathrm{s},-\mathrm{OCH}_{3}\right), 5.05(2 \mathrm{H}, \mathrm{m}$, 6-位および 10-位の C=C-H)，5.64(1 H,br s 2-位の C=C-H) で このものをエーテル中, $\mathrm{LiAlH}_{4}$ で還元し, trans, trans-ファル

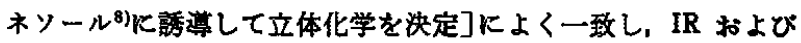
MS む完全に一致した。

ピーク29の MS スベクトルは M! m/e 264(20)を元し, 無水 䣫酸, ピリジンを用い, trans, trans-ファルネソールをフセチ ル化して合成した trans, transーファルネシル=アセタートと MS スベクトルならびに GLC の $t_{\mathrm{R}}{ }^{9}(14.13 \mathrm{~min})$ が一致したことか ら, ピーク 29 は trans, trans-ファルネシル=フセタートである ことを碓㒛した。

7） s は一重線， m は多荲線，br は愊広いシクナルであるこ とを示す。

8) R. B. Bates, D. M. Gale, B. J. Gruner, J. Org. Chem., 28, 1086(1963).

9) E. J. Corey, N. W. Gilman, B. E. Ganem, J. Am. Chem. Soc., 90, 5616(1968).

10) L. Ruzicka, Helv. Chim. Acta, 6, 491(1923).

11) J. Attenburrow, A. F. B. Cameron, J. H. Chapman, R. M. Evans, B. A. Herms, A. B. A. Jansen, T. Walker, J. Chem.Soc., 1952, 1094. 
ピーク 28, 30 の GLC の $t_{\mathrm{R}}, \mathrm{MS}, \mathrm{IR}, \mathrm{UV}, \mathrm{NMR}$ スベク トルが票品および文献212)のそれと一致したことから，それぞれ

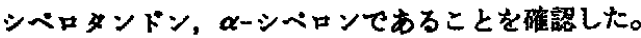

\section{3 結果と孝察}

ミズガヤシリおよびハマスゲの塊荃の精油成分をCC あるいは GLC 分取し単離媵，おるに機器分析，一部は化学的手段で得た データを標品のそれと比较同定を行ない，その結果を表 1 K示し た。

两精油とるセスキテルペンが主成分で， $\boldsymbol{\beta}$ 一セりネンはいずれに る存在し：ミズガヤッリ精油は，他に $\beta$-エレメン,カリオフィ レン， $\alpha$ ーフムレンを主成分として含み，ハマスゲ精油はそのかわ

12) R. Howe, F.J.Mcguillin, J. Chem. Soc., 1955, 2423 ;

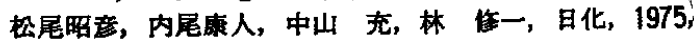

クスシペレンを含を。

含酸素化合物はミズガヤツリ䊑油に trans, trans-ファルネス 酸メチルと䣫酸 trans, transーファルネシルの鎖状セスキテルヘ ンェステルが主成分であるのに，八マスゲ精油慓状セスキテル ペンタトン, $\alpha$-シペロンであった。

ファルネセン酸メチルは精油成分として初めて赫告されるが， Bowers ら ${ }^{18)}$ とより幼若ホルそンとして坛告されている。10，11エポキシファルネス酸メチルと類緑の化合物であることは興味滐 ڤ。

本研究にあたり、ファルネス酸を患与くださった塩野香料株式 会社国重 勤氏飞樑諎します。

2188.

13) W.S. Bowers, M. J. Thomson, E.C. Uebel, Life Sci, 4. $2323(1965)$

The Constituents of Essential Oils of Cyperus serotinus Rottb. and Cyperus rotundus $\mathrm{L}$.

Jun-ichi Iwamura*, Minoru Kameda*, Koichiro Komai** and Nenokichi HIRAO**

* Department of Applied Chemistry, Faculty of Science and Engineering, Kinki University; Kowakae, Higashi-osaka-shi 577 Japan

** Department of Agricultural Chemistry, Faculty of Agriculture, Kinki University; Kowakae, Higashi-osaka-shi 577 Japan

An essential oil was obtained from tubers of Mizugayatsuri (Cyperus serotinus Rottb.) by steam distillation in $0.02 \%$ yield, whose property being $d_{4}^{80} 1.0367, n_{D}^{30} 1.4949$, and $[\alpha]={ }_{D}^{34} \pm 0^{\circ}(c=$ $0.9, \mathrm{CHCl}_{3}$ ).

The components were separated by means of column and gas chromatography, and as a main component, $\beta$-elemene, caryophyllene, $\alpha$-humulene, $\beta$-selinene, methyl trans, trans-farnesate, trans, trans-farnesyl acetate, or $\alpha$-cyperone, and as a minor one, $\alpha$-copaene, $\beta$-santalene, $\beta$ guaiene, $\delta$-cadinene, calamene, or cyperotundone was identified in terms of IR, MS and NMR

For comparison, the essential oil of Cyperus rotundus L. was analyzed, but methyl farnesate or farnesyl acetate could not be found. 